\title{
Dietary minerals, reproductive hormone levels and sporadic anovulation: associations in healthy women with regular menstrual cycles
}

\author{
Keewan Kim ${ }^{1}$, Jean Wactawski-Wende ${ }^{2}$, Kara A. Michels ${ }^{1}$, Karen C. Schliep ${ }^{3}$, Torie C. Plowden ${ }^{1,4}$, \\ Ellen N. Chaljub ${ }^{1}$ and Sunni L. Mumford ${ }^{1 *}$ \\ ${ }^{1}$ Division of Intramural Population Health Research, Eunice Kennedy Shriver National Institute of Child Health and Human \\ Development, National Institutes of Health, Bethesda, MD 20817, USA \\ ${ }^{2}$ Department of Epidemiology and Environmental Health, University at Buffalo, State University of New York, Buffalo, NY 14214, USA \\ ${ }^{3}$ Department of Family and Preventive Medicine, University of Utab Health Sciences Center, Salt Lake City, UT 84108, USA \\ ${ }^{4}$ Program in Reproductive and Adult Endocrinology, Eunice Kennedy Shriver National Institute of Child Health and Human \\ Development, National Institutes of Health, Bethesda, MD 20817, USA
}

(Submitted 1 September 2017 - Final revision received 23 February 2018 - Accepted 28 February 2018 - First published online 20 April 2018)

\section{Abstract}

Although minerals are linked to several reproductive outcomes, it is unknown whether dietary minerals are associated with ovulatory function. We hypothesised that low intakes of minerals would be associated with an increased risk of anovulation. We investigated associations between dietary mineral intake and both reproductive hormones and anovulation in healthy women in the BioCycle Study, which prospectively followed up 259 regularly menstruating women aged 18-44 years who were not taking mineral supplements for two menstrual cycles. Intakes of ten selected minerals were assessed through 24-h dietary recalls at up to four times per cycle in each participant. Oestradiol, progesterone, luteinising hormone (LH), follicle-stimulating hormone (FSH), sex-hormone-binding globulin and testosterone were measured in serum up to eight times per cycle. We used weighted linear mixed models to evaluate associations between minerals and hormones and generalised linear models for risk of anovulation. Compared with $\mathrm{Na}$ intake $\geq 1500 \mathrm{mg}$, Na intake $<1500 \mathrm{mg}$ was associated with higher levels of FSH $(21.3 \% ; 95 \%$ CI 7.5, 36.9) and LH $(36 \cdot 8 \% ; 95 \%$ CI 16.5, 60.5) and lower levels of progesterone $(-36 \cdot 9 \% ; 95 \%$ CI $-56 \cdot 5,-8 \cdot 5)$. Na intake $<1500 \mathrm{mg}$ (risk ratio (RR) $2 \cdot 70 ; 95 \%$ CI 1.00, 7.31) and Mn intake <1.8 mg (RR 2.00; $95 \%$ CI 1.02, 3.94) were associated with an increased risk of anovulation, compared with higher intakes, respectively. Other measured dietary minerals were not associated with ovulatory function. As essential minerals are mostly obtained via diet, our results comparing insufficient levels with sufficient levels highlight the need for future research on dietary nutrients and their associations with ovulatory cycles.

\section{Keywords: Dietary minerals: Reproductive hormones: Anovulation: Premenopausal women}

Minerals are inorganic elements that are essential for normal physiologic function and are widely involved in a broad range of processes including cellular metabolism and antioxidant and anti-inflammatory defences ${ }^{(1,2)}$. They have critical roles in enzyme activity as co-factors or catalysts ${ }^{(3,4)}$, and contribute to protein synthesis ${ }^{(5)}$ and the regulation of gene expression ${ }^{(6)}$. Mineral homoeostasis in the body system is tightly regulated, and deficiencies in essential minerals may in turn affect a wide range of physiological processes ${ }^{(7,8)}$.

There is ample evidence showing that minerals are important for reproductive function in women. In particular, minerals may be associated with ovulation, as demonstrated by induced ovulation upon administration of $\mathrm{Cu}$ in animals following stimulation of the hypothalamus ${ }^{(9)}$, or by acting as antioxidants in controlling oxidative stress, which has been shown to promote ovulation $^{(10)}$. In maturing mammalian oocytes, $\mathrm{Zn}$ accumulates as oocytes grow and regulates meiosis ${ }^{(11,12)}$, and as such may also be important for reproductive health. Higher levels of $\mathrm{Cu}, \mathrm{Zn}^{(13)}$, $\mathrm{Ca}$ and $\mathrm{Mn}^{(14)}$ were measured in women with polycystic ovary syndrome and an inverse association between Fe intake and ovulatory infertility was suggested ${ }^{(15)}$, all pointing to possible relations between essential minerals and reproductive health outcomes.

To date, most studies on minerals and reproductive function, particularly reproductive hormones, have been conducted using serum mineral concentrations ${ }^{(16-18)}$ or animal models ${ }^{(19,20)}$. Although diet is a major source of essential minerals in the general population, there are very few studies using dietary assessments to explore associations between minerals and reproductive function. Therefore, our objective was to investigate

Abbreviations: FSH, follicle-stimulating hormone; LH, luteinising hormone; Ca, calcium; P, phosphorus; Mg, magnesium; Fe, iron; Zn, zinc; Cu, copper; Mn, manganese; Se, selenium; Na, sodium; K, potassium.

* Corresponding author: S. L. Mumford, email mumfords@mail.nih.gov 
the associations between the dietary intakes of ten minerals and two primary outcomes including (1) reproductive hormones and (2) anovulation in healthy, regularly menstruating women who were not taking dietary supplements. We hypothesised that intake of dietary minerals below the recommended levels would be associated with changes in reproductive hormone concentrations and an increased risk of anovulation. Although exploratory, our study provides a comprehensive examination of the influence of dietary minerals among healthy women.

\section{Methods}

\section{Study design and sample collection}

The BioCycle Study is a prospective cohort study that recruited 259 healthy regularly menstruating women from Western New York in 2005-2007. Details of the study design and sample collection are described elsewhere ${ }^{(21)}$. In brief, women aged 18-44 years with self-reported menstrual cycle lengths of 21-35d for at least 6 months before recruitment and selfreported BMI of $>18$ or $<35 \mathrm{~kg} / \mathrm{m}^{2}$ at screening were eligible for the study. Women were excluded if they used hormonal contraceptives in the past 3 months before screening, were pregnant or breast-feeding in the past 6 months, had a history of ovulatory disorders or uterine abnormalities or were taking vitamin or mineral supplements during the study period. Participants provided information on age, race, lifestyle and reproductive and health history by means of questionnaires at baseline. Each participant also completed the International Physical Activity Questionnaire (IPAQ) long form 2002, and we estimated their physical activity as high, moderate and low based on standard IPAQ cut-offs. Trained research staff measured weight and height according to standardised protocols at baseline.

Each participant provided fasting blood specimens up to eight times per cycle during her visits at specific phases of the menstrual cycle, including menstruation, mid-follicular phase and late follicular phase, luteinising hormone (LH) surge, estimated day of ovulation and early, mid- and late luteal phase. Fertility monitors (Clearblue Easy Fertility Monitor; Inverness Medical) and personal cycle length histories were used to determine the timing of visits ${ }^{(2)}$. In total, we collected data for two cycles from 250 women and one cycle from nine women; $94 \%$ of the participants completed at least seven clinic visits per cycle. The University at Buffalo Health Sciences Institutional Review Board (IRB) served as the IRB designated by the National Institutes of Health under a reliance agreement and approved the study. All study participants provided written informed consent.

\section{Dietary assessment}

We obtained dietary data through 24-h dietary recalls completed by study participants when they visited the clinic during the menstruation, mid-follicular, ovulation and mid-luteal phases of each cycle. Approximately $87 \%$ of participants completed four dietary recalls per cycle; $13 \%$ of women completed three recalls per cycle; and $0.4 \%$ of women completed only two. We used the Nutrition Data System for Research software version 2005 (the Nutrition Coordinating Center, University Minnesota) to estimate intakes of dietary minerals, including $\mathrm{Ca}$ (mg), P (mg), Mg (mg), Fe (mg), Zn (mg), Cu (mg), Mn (mg), $\mathrm{Se}(\mu \mathrm{g}), \mathrm{Na}(\mathrm{mg})$ and $\mathrm{K}(\mathrm{mg})$ from food and beverage intakes. $\mathrm{Na}$ intake captures amounts that were naturally occurring in foods and those that were added during food processing; however, it does not include $\mathrm{Na}$ from any added table salt. We categorised daily intakes of dietary minerals by their recommended dietary allowance (RDA). The RDA for each mineral are as follows: $1000 \mathrm{mg}$ for $\mathrm{Ca}, 700 \mathrm{mg}$ for $\mathrm{P}, 310 \mathrm{mg}$ for $\mathrm{Mg}$, $18 \mathrm{mg}$ for $\mathrm{Fe}, 8 \mathrm{mg}$ for $\mathrm{Zn}, 0.9 \mathrm{mg}$ for $\mathrm{Cu}, 1.8 \mathrm{mg}$ for $\mathrm{Mn}, 55 \mu \mathrm{g}$ for Se and $1500 \mathrm{mg}$ for $\mathrm{Na}^{(23)}$. Mean levels of $\mathrm{K}$ intake were below the RDA $(4700 \mathrm{mg}$ ) in all of our participants, as such $\mathrm{K}$ intake was categorised by the US average of $2227 \mathrm{mg} / \mathrm{d}^{(24)}$. As intakes were not observed to change over the cycle, except for $\mathrm{Zn}$, which showed minimal variability ${ }^{(25)}$, we averaged the intake of dietary minerals per cycle for these analyses. Total energy intake was also averaged per cycle given that we did not observe changes across the cycle ${ }^{(25)}$, although another study has noted fluctuations ${ }^{(26)}$.

\section{Reproductive hormone measurement}

Details of hormonal analyses were previously reported ${ }^{(27)}$. Concentrations of total oestradiol, follicle-stimulating hormone (FSH), LH, progesterone and sex-hormone-binding globulin (SHBG) were measured using solid-phase competitive chemiluminescent enzymatic immunoassays (Specialty Laboratories Inc.) on a DPC Immulite 2000 analyzer (Siemens Medical Solutions Diagnostics) at the Kaleida Health Center for Laboratory Medicine. Total testosterone concentrations (ng/dl) were measured by liquid chromatography/tandem MS using a Shimadzu Prominence Liquid Chromatograph (Shimadzu Scientific Instruments, Inc.) with an ABSceix 5500 tandem mass spectrometer (AB SCIEX) at the University of Minnesota. Increased sensitivity was obtained using Mobile Phase B (100\% acetonitrile) with a low standard of $4 \mathrm{ng} / \mathrm{dl}$ added to the standard curve. Free (i.e. bioavailable) oestradiol and testosterone and free androgen index were calculated based on standardised methods ${ }^{(28)}$. The coefficient of variation (CV) was $<10 \%$ for oestradiol and SHBG, $<5 \%$ for $\mathrm{LH}$ and $\mathrm{FSH},<14 \%$ for progesterone and $<7 \%$ for total testosterone. We defined sporadic anovulatory cycles as cycles with peak progesterone concentrations $\leq 5 \mathrm{ng} / \mathrm{ml}$ and no observed serum $\mathrm{LH}$ peak during the mid-luteal or late luteal phase cycle visit (in the event that timing of progesterone measurement was too early) ${ }^{(29)}$. In total, forty-two of the 509 cycles $(8.3 \%)$ in the study were considered anovulatory.

\section{Statistical analysis}

Distributions of demographic variables were characterised by intakes of dietary minerals below or above the RDA or the US average intake for K. We used Fisher's exact test or Student's $t$ test to compare the demographic variables as appropriate. We calculated Pearson's correlation coefficients among personaveraged dietary mineral intakes.

Associations between dietary minerals and serum reproductive hormones were assessed by weighted linear mixed models 
with random intercepts. Cycle-averaged dietary minerals were evaluated in quintiles (comparing lower intakes with the highest intake quintile) and as dichotomised by the RDA or US average. Models were adjusted for age, BMI, race, physical activity, Mediterranean diet score, intakes of total energy, fibre and protein, as well as other hormone concentrations. Inverse probability weights were used to account for the complex feedback mechanisms between changing reproductive hormone levels over the menstrual cycle $\mathrm{e}^{(30,31)}$. The results are presented as percent difference in hormone levels with $95 \% \mathrm{CI}$. We adjusted all models of dietary mineral intake and reproductive hormones for the false discovery rate using the Benjamini-Hochberg procedure within each dietary mineral group (i.e. $\mathrm{Ca}, \mathrm{P}, \mathrm{Mg}$ and so on) to account for multiple comparisons.

We used Poisson regression with robust error variance estimates to investigate the risk of sporadic anovulation with dietary mineral intakes by quintiles and RDA. All sporadic anovulation models were adjusted for age, BMI, race, physical activity, Mediterranean diet score and intakes of energy, fibre and protein. We report estimates as risk ratios (RR) and 95\% CI. SAS version 9.4 (SAS Institute) was used for all statistical analyses.

\section{Results}

Average daily intake of minerals, including $\mathrm{P}, \mathrm{Cu}, \mathrm{Mn}$, Se and $\mathrm{Na}$, were above the RDA in more than half of our participants, whereas intakes of $\mathrm{Ca}, \mathrm{Mg}$ and $\mathrm{Fe}$ above the RDA were observed in only about $10 \%$ of women (Table 1 ). The mean age of our participants was significantly higher among women whose intakes of dietary P (27.7 (SD 8.3) years) and $\mathrm{Zn}(28.8$ (SD 8.7) years) were greater than the RDA and whose $\mathrm{K}$ was greater than the US average (30.0 (sD 8.8) years), compared with those who consumed less (24.8 (sD 7.1) for P, 25.9 (sD 7.5) for $\mathrm{Zn}$ and 26.4 (sD 7.8) for K). Intakes of dietary $\mathrm{Ca}, \mathrm{P}, \mathrm{Mg}, \mathrm{Zn}, \mathrm{Cu}$ and $\mathrm{K}$ were significantly different by race. Dietary minerals assessed in our study were all significantly correlated to each other $(P<0 \cdot 0001 ;$ Table 2). The highest correlations were detected between $\mathrm{Mg}$ and $\mathrm{Mn}(r$ 0.85), whereas the least correlated minerals were $\mathrm{Ca}$ and $\mathrm{Cu}(r 0.33)$ and $\mathrm{Zn}$ and $\mathrm{Mn}(r 0.33)$.

Compared with Ca intake above the RDA ( $\geq 1000 \mathrm{mg})$, intake of $\mathrm{Ca}<\mathrm{RDA}$ was associated with lower progesterone concentrations (-20.0\% difference; 95\% CI -34.9, -1.9; Table 3), adjusted for age, BMI, race, physical activity, intakes of energy, Mediterranean diet score, fibre and protein, as well as other hormones. Intake of $\mathrm{Mg}$ below the RDA $(<310 \mathrm{mg})$ was inversely associated with testosterone $(-4.7 \%$ difference; $95 \% \mathrm{CI}$ $-9 \cdot 2,0 \cdot 0)$, relative to above the RDA. However, these results did not persist after adjusting for false discovery rate. We found that intake of $\mathrm{Na}$ below the RDA ( $<1500 \mathrm{mg}$ ) was associated with higher concentrations of FSH (21.3\% change; $95 \%$ CI $7 \cdot 5,36 \cdot 9)$ and $\mathrm{LH}(36.8 \%$ change; $95 \%$ CI $16.5,60.5)$, and lower concentrations of progesterone ( $-36.9 \%$ change; $95 \%$ CI $-56 \cdot 5$, -8.5), compared with $\mathrm{Na}$ intake above the RDA ( $\geq 1500 \mathrm{mg})$. Stratified by the US average intake, we detected inverse associations between $\mathrm{K}$ intake $<2227 \mathrm{mg}$ and free androgen index $(5.7 \%$ change; $95 \%$ CI $-0.1,11.9)$, relative to intake of $\mathrm{K} \geq 2227 \mathrm{mg}$, although the result was no longer significant after adjusting for false discovery rate. Compared with the highest quintile, the lowest quintiles of $\mathrm{Fe}$ and $\mathrm{Zn}$ were associated with lower progesterone $(-36.4 \%$ difference; $95 \%$ CI $-53 \cdot 4,-13.4)$ and LH ( $-14 \cdot 0 \%$ difference; $95 \%$ CI $-24 \cdot 1,-2 \cdot 6)$, respectively (online Supplementary Table S1).

Compared with intakes of minerals above the RDA, intakes of Mn <1.8 mg (RR 2.00; $95 \%$ CI 1.02, 3.94) and $\mathrm{Na}<1500 \mathrm{mg}$ (RR $2 \cdot 70 ; 95 \%$ CI $1.00,7 \cdot 31)$ were associated with an increased risk of sporadic anovulation, adjusted for age, BMI, race, physical activity, Mediterranean diet score and intakes of energy, fibre and protein (Table 4). Intake of Se $<55 \mu \mathrm{g}$ was associated with increased risk for sporadic anovulation (RR 2.66; $95 \%$ CI 0.96, 7.36), relative to Se intake $\geq 55 \mu \mathrm{g}$. In general, no significant associations were detected when dietary minerals were assessed in quintiles (online Supplementary Table S2).

\section{Discussion}

Overall, our data suggest associations between intakes of specific dietary minerals, particularly $\mathrm{Na}$ intake, and reproductive hormones in normally menstruating women of reproductive age. Our data also indicate associations between insufficient intakes of $\mathrm{Mn}$ and $\mathrm{Na}$ and an increased risk of sporadic anovulation, although the majority of dietary minerals that we evaluated were not associated with the risk of anovulation. As our assessed minerals are abundant in easily accessible food items, our data suggest that specific dietary factors may influence reproductive hormones and ovulation among healthy women.

We observed associations between dietary $\mathrm{Na}$ intake below the RDA and higher FSH and LH concentrations, lower progesterone levels and an increased risk of sporadic anovulation. High intake of $\mathrm{Na}$ has been associated with increased levels of steroid hormones, such as glucocorticoids, in 370 adults $^{(32)}$; however, studies evaluating the potential role of dietary $\mathrm{Na}$ on changes of other hormone levels are scarce, limiting comparison with our work. One experimental study conducted in male rats reported increased levels of $\mathrm{FSH}$ and testosterone and decreased levels of LH in rats fed a high-salt diet compared with controls fed a low-salt diet ${ }^{(33)}$. Sufficient levels of $\mathrm{Na}$ intake might be important for mammalian reproduction, as suggested in an animal study, which detected significantly lower mating and fewer litters in mice fed low-Na foods, compared with mice fed high-Na foods ${ }^{(34)}$. Specific biological mechanisms linking $\mathrm{Na}$ intake and ovulatory function are limited, although this could be perhaps similar to a relationship between $\mathrm{Na}$ and inflammation. Positive associations between Na and inflammation were suggested in a cross-sectional analysis of 1597 individuals in whom 24-h $\mathrm{Na}$ excretion was associated with increases in serum C-reactive protein concentration, a global marker of inflammation ${ }^{(35)}$. As ovulation is considered an acute inflammatory process ${ }^{(36)}$, our finding on the association between $\mathrm{Na}$ intake below the RDA and increased risk of anovulation could be partly related to this mechanism. Nonetheless, because $\mathrm{Na}$ intake assessed in our study does not reflect $\mathrm{Na}$ from salt added at the table, exposure misclassification is possible. Despite the fact that $\mathrm{Na}$ is an essential mineral, excessive consumption is related to adverse health conditions such as high blood pressure and $\mathrm{CVD}^{(37)}$, and thus our result should be interpreted carefully. 
Table 1. Characteristics of the study cohort by dietary mineral intakes less than or greater than daily RDA (Mean values and standard deviations; numbers and percentages)

\begin{tabular}{|c|c|c|c|c|c|c|c|c|c|c|c|c|c|c|c|c|c|c|c|c|}
\hline \multirow[b]{3}{*}{ Demographics (\%) } & \multicolumn{4}{|c|}{$\mathrm{Ca}(\mathrm{mg})$} & \multicolumn{4}{|c|}{$\mathrm{P}(\mathrm{mg})$} & \multicolumn{4}{|c|}{$\mathrm{Mg}(\mathrm{mg})$} & \multicolumn{4}{|c|}{$\mathrm{Fe}(\mathrm{mg})$} & \multicolumn{4}{|c|}{$\mathrm{Zn}(\mathrm{mg})$} \\
\hline & \multicolumn{2}{|c|}{$<1000$} & \multicolumn{2}{|c|}{$\geq 1000$} & \multicolumn{2}{|c|}{$<700$} & \multicolumn{2}{|c|}{$\geq 700$} & \multicolumn{2}{|c|}{$<310$} & \multicolumn{2}{|c|}{$\geq 310$} & \multicolumn{2}{|c|}{$<18$} & \multicolumn{2}{|c|}{$\geq 18$} & \multicolumn{2}{|c|}{$<8$} & \multicolumn{2}{|c|}{$\geq 8$} \\
\hline & Mean & SD & Mean & SD & Mean & SD & Mean & SD & Mean & SD & Mean & SD & Mean & SD & Mean & SD & Mean & SD & Mean & SD \\
\hline$n$ & \multirow{2}{*}{\multicolumn{2}{|c|}{$\begin{array}{l}226 \\
87.3\end{array}$}} & \multicolumn{2}{|c|}{33} & \multicolumn{2}{|c|}{36} & & & 23 & & & & & & 26 & & 1 & & & \\
\hline$\%$ & & & 12 & & & & & & 89 & & 10 & & & & 10 & & 5 & & & \\
\hline Age (years) & $27 \cdot 0$ & $8 \cdot 1$ & $29 \cdot 6$ & 8.7 & $24.8 \dagger$ & $7 \cdot 1 \dagger$ & $27 \cdot 7 \dagger$ & $8.3 \dagger$ & $27 \cdot 2$ & $8 \cdot 1$ & $27 \cdot 7$ & 9.2 & $27 \cdot 1$ & 8.0 & 28.9 & $9 \cdot 6$ & $25 \cdot 9 \dagger$ & $7.5 \dagger$ & $28.8 \dagger$ & $8.7 \dagger$ \\
\hline $\mathrm{BMI}\left(\mathrm{kg} / \mathrm{m}^{2}\right)$ & $24 \cdot 0$ & 3.8 & $24 \cdot 6$ & $4 \cdot 3$ & 24.6 & 4.0 & 24.0 & 3.8 & $24 \cdot 2$ & 3.8 & 23.4 & 4.3 & $24 \cdot 1$ & 3.9 & 24.2 & 3.5 & 23.8 & 3.6 & 24.3 & $4 \cdot 1$ \\
\hline Race & & & & & & & & & & & & & & & & & & & & \\
\hline White & & & & & & & & & & & & & & & 73 & & & & & \\
\hline Black & & & & & & & & & & & & & & & 7 & & & & & \\
\hline Other & & & & & & & & & & & & & & & 19 & & & & & \\
\hline Physical activity & & & & & & & & & & & & & & & & & & & & \\
\hline Low & 10 & & & & & & & & 10 & & & & & & 3 & & & & & \\
\hline Moderate & & & 39 & & & & & & 34 & & & & & & 42 & & & & & \\
\hline High & 5 & & 57 & & & & & & 55 & & 50 & & & & 53 & & $4 \varepsilon$ & & & \\
\hline$\leq$ High school education & 13 & & & & & & & & 13 & & & & & & 7 & & 1 & & & \\
\hline Current smoker & & & & & & & & & & & & & & & 3 & & & & & \\
\hline Married & 23 & & 36 & & & & & & 24 & & 35 & & & & 23 & & 2 & & & \\
\hline Nulliparous & 72 & & 57 & & & & & & 72 & & 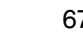 & & & & 73 & & & & & \\
\hline Past OC Use & 5 & & 63 & & & & & & 53 & & 57 & & & & 57 & & $4 \varsigma$ & & 5 & \\
\hline & & & & & & & ng) & & & & & & & $\mathrm{Na}$ & & & & & & \\
\hline & & & $\geq 0$ & & & & & & $<$ & & & & & & $\geq 15$ & & $<2$ & & & \\
\hline$n$ & & & 15 & & & & & & 1 & & & & & & 25 & & 1 & & 6 & \\
\hline$\%$ & & & & & & & & & & & & & & & 98 & & & & 25 & \\
\hline Age (years) & $26 \cdot 8$ & 8.4 & $27 \cdot 6$ & 8.1 & $25 \cdot 8$ & $8 \cdot 2$ & $27 \cdot 6$ & 8.2 & $26 \cdot 2$ & $7 \cdot 1$ & $27 \cdot 4$ & 8.3 & $25 \cdot 0$ & $5 \cdot 1$ & $27 \cdot 3$ & 8.3 & $26.4 \dagger$ & $7.8 \dagger$ & $30.0 \dagger$ & $8.8 \dagger$ \\
\hline $\mathrm{BMI}\left(\mathrm{kg} / \mathrm{m}^{2}\right)$ & $24 \cdot 3$ & 3.8 & 23.9 & 3.9 & 24.6 & 3.9 & 24.0 & 3.9 & $24 \cdot 3$ & $4 \cdot 2$ & 24.1 & 3.8 & $24 \cdot 0$ & 4.4 & $24 \cdot 1$ & 3.9 & $24 \cdot 1$ & 3.8 & 24.0 & $4 \cdot 1$ \\
\hline Race & & & & & & & & & & & & & & & & & & & & \\
\hline White & & & & & & & & & 50 & & 60 & & & & 59 & & & & & \\
\hline Black & & & & & & & & & 18 & & 15 & & & & 19 & & & & & \\
\hline Other & & & & & & & & & 31 & & 20 & & & & 20 & & & & & \\
\hline Physical activity & & & & & & & & & & & & & & & & & & & & \\
\hline Low & $1<$ & & & & & & & & & & & & & & 9 & & & & & \\
\hline Moderate & 32 & & 37 & & & & & & 50 & & 3 & & & & 35 & & 35 & & 36 & \\
\hline High & 5 & & 56 & & & & & & 43 & & 55 & & & & 54 & & & & 58 & \\
\hline$\leq$ High school education & & & & & & & & & 12 & & & & & & 12 & & & & & it \\
\hline Current smoker & & & & & & & & & & & & & & & 3 & & & & & \\
\hline Married & 15 & & 29 & & & & & & 12 & & 26 & & & & 25 & & & & & \\
\hline Nulliparous & 75 & & 70 & & & & & & 75 & & 72 & & & & 72 & & & & & \\
\hline Past OC Use & 47 & & $5 \varepsilon$ & & & & & & 37 & & 55 & & & & 53 & & & & & \\
\hline
\end{tabular}

OC, oral contraceptive.

* Cycle-averaged daily intake of dietary K was categorised by the US average intake (e.g. $2227 \mathrm{mg})$. $P$ values for continuous variables were calculated using Student's $t$ test, and for categorical variables using Fisher's exact test. † Statistically significant differences $(P<0.05)$. 
Mineral intakes and ovulatory function

Table 2. Correlations among average dietary mineral intakes across both cycles $(n 259)^{\star}$

\begin{tabular}{|c|c|c|c|c|c|c|c|c|c|c|}
\hline & $\mathrm{Ca}$ & $\mathrm{P}$ & $\mathrm{Mg}$ & $\mathrm{Fe}$ & $\mathrm{Zn}$ & $\mathrm{Cu}$ & $\mathrm{Mn}$ & $\mathrm{Se}$ & $\mathrm{Na}$ & $\mathrm{K}$ \\
\hline $\mathrm{Ca}$ & 1.00 & 0.81 & 0.57 & 0.51 & 0.41 & 0.33 & 0.38 & 0.38 & 0.47 & 0.60 \\
\hline$P$ & & 1.00 & 0.78 & 0.57 & 0.48 & 0.52 & 0.56 & 0.70 & 0.71 & 0.80 \\
\hline $\mathrm{Mg}$ & & & 1.00 & 0.61 & 0.42 & 0.60 & 0.85 & 0.51 & 0.47 & 0.83 \\
\hline $\mathrm{Fe}$ & & & & 1.00 & 0.59 & 0.44 & 0.58 & 0.46 & 0.51 & 0.52 \\
\hline $\mathrm{Zn}$ & & & & & 1.00 & 0.48 & 0.33 & 0.36 & 0.38 & 0.42 \\
\hline $\mathrm{Cu}$ & & & & & & 1.00 & 0.48 & 0.34 & 0.38 & 0.56 \\
\hline $\mathrm{Mn}$ & & & & & & & 1.00 & 0.41 & 0.34 & 0.58 \\
\hline $\mathrm{Se}$ & & & & & & & & 1.00 & 0.70 & 0.51 \\
\hline $\mathrm{Na}$ & & & & & & & & & 1.00 & 0.57 \\
\hline $\mathrm{K}$ & & & & & & & & & & 1.00 \\
\hline
\end{tabular}

${ }^{*}$ All were statistically significant $(P<0.0001)$.

An association between Mn intake below the RDA and an increased risk for sporadic anovulation was indicated in our study, although we did not detect any associated changes in hormones. The impact of Mn on women's reproductive health has been investigated in relation to pubertal development in prior work. Specifically, in animal studies using prepubertal female rats, a significant increase in serum LH levels was detected upon $\mathrm{MnCl}_{2}$ treatment ${ }^{(17,38)}$. Given that $\mathrm{Mn}$ is abundant in easily obtainable foods (e.g. teas, nuts, legumes and whole grains), further investigation into the particular sources of dietary Mn and improved ovulatory function could be beneficial for women of reproductive age.

Although our data do not support hormonal differences in relation to dietary Se, intake of Se below the RDA was associated with an increased risk for sporadic anovulation. Owing to its antioxidant properties, greater attention has been given to Se in relation to fertility. A significantly higher level of glutathione peroxidase activity, an enzyme containing Se, was observed in menstruating women compared with women without regular menstruation $^{(39)}$, and plasma Se was related to oestradiol concentrations across the menstrual cycle ${ }^{(40)}$. In addition, Se was positively associated with progesterone concentrations in adolescent girls, a marker of ovulatory function, in research specifically investigating Se status, sex hormone secretion and thyroid metabolism ${ }^{(41)}$. Combined with previous studies using Se measured in blood, our data using dietary Se may also perhaps underscore a potential role of Se in ovulatory function in healthy women.

Our data suggested an association between dietary Ca and progesterone, although the result was no longer significant after adjusting for false discovery rate. Nevertheless, this association is in line with an experimental study, which demonstrated an association between $\mathrm{Ca}$ and progesterone in ovarian follicle cells ${ }^{(42)}$. Although we did not detect any associations between $\mathrm{Ca}$ and oestradiol, prior studies reported a relation between $\mathrm{Ca}$ and oestrogen metabolism in women ${ }^{(43-45)}$, suggesting a possible interaction between $\mathrm{Ca}$ and oestrogen and link with other oestrogen-dependent conditions, such as endometriosis $^{(46)}$. We recently reported no association between $\mathrm{Ca}$ consumption via dairy intake and sporadic anovulation ${ }^{(47)}$, and our findings regarding overall dietary $\mathrm{Ca}$ intake in this analysis were similar. In a separate analysis, we did not detect any significant changes in $\mathrm{Ca}$ measured in diet across the cycle overall and by anovulation status. Therefore, our null results might be owing to the fact that any changes in dietary Ca over the cycle are very small and are not subsequently associated with reproductive hormones and ovulation measured in our study.

We further observed that insufficient dietary intakes of $\mathrm{Mg}$ were associated with lower testosterone levels, although the association did not remain after adjustment for multiple comparisons. Influence of $\mathrm{Mg}$ on hormonal change has been suggested in an experimental study that showed that changes in $\mathrm{Mg}$ status were associated with changes in testosterone and $\mathrm{SHBG}^{(48)}$. Previously, a study of twenty-five post-menopausal women and fifteen premenopausal women reported no association between serum $\mathrm{Mg}$ concentrations and testosterone, although an inverse association with oestrogen was detected $^{(16)}$. Our measurement of $\mathrm{Mg}$ via dietary intake is different from the serum measurement, as the latter may reflect overall $\mathrm{Mg}$ status in the body system. Still, our data suggest the importance of $\mathrm{Mg}$ in maintaining the level of bioavailable testosterone for women of reproductive age.

Consumption of $\mathrm{K}$ was lower than the RDA for all participants in our study, which is consistent with the US general population, where average intakes of dietary $\mathrm{K}$ are substantially lower than the RDA ( $4700 \mathrm{mg}$ ) among both men and women ${ }^{(23)}$. Stratifying intake by the US average, we found that intake of K below the US average was associated with higher testosterone, free testosterone and free androgen index, although the results were no longer significant after adjusting for false discovery rate. In an experimental study, $\mathrm{K}$ demonstrated a regulatory role in plasma testosterone levels ${ }^{(19)}$, potentially supporting our observation between $\mathrm{K}$ and androgen levels. Although we observed associations between testosterone levels and consumption of $\mathrm{K}$, this did not translate into associations with the risk of anovulation in healthy regularly menstruating women.

Our study has several limitations. In an animal study, a role of reproductive hormones on $\mathrm{Na}$ consumption has been suggested, possibly through the sympathetic nervous system, which could be influenced by oestradiol and drive Na intake in turn $^{(49)}$. Therefore, it is possible that the intakes of certain dietary minerals, particularly $\mathrm{Na}$, could be affected by hormonal changes specific to cycle phase. However, this might be of less concern as we used longitudinal modelling with inverse probability weighting to account for changing levels of endogenous reproductive hormones over the menstrual cycle, and we did not observe changes in intakes over the cycle. As the women in our study were instructed not to take any mineral supplements 
Table 3. Associations between dietary mineral intakes and reproductive hormone concentrations by daily RDA* (Percentage differences in hormone concentrations and $95 \%$ confidence intervals)

\begin{tabular}{|c|c|c|c|c|c|c|c|}
\hline \multirow[b]{3}{*}{$\mathrm{Ca}(\mathrm{mg})$} & \multirow[b]{2}{*}{$<\mathrm{RDA}$} & \multirow[b]{2}{*}{$\geq \mathrm{RDA}$} & \multicolumn{3}{|c|}{$<\mathrm{RDA} v . \geq \mathrm{RDA}$ (ref) } & \multirow[b]{2}{*}{ Raw $(P)$} & \multirow{2}{*}{$\begin{array}{l}\text { Adjusted for false } \\
\text { discovery rate }(P)\end{array}$} \\
\hline & & & $\%$ Difference & & & & \\
\hline & $150 \cdot 0-999.1$ & $1005 \cdot 3-1963 \cdot 7$ & & & & & \\
\hline Oestradiol (pg/ml) & & & -3.4 & $-10 \cdot 8$ & 4.7 & 0.397 & 0.921 \\
\hline Free oestradiol $(\mathrm{pg} / \mathrm{ml})$ & & & $-4 \cdot 0$ & $-11 \cdot 2$ & 3.8 & 0.301 & 0.921 \\
\hline $\mathrm{FSH}(\mathrm{mlU} / \mathrm{ml})$ & & & 0.6 & -5.9 & $7 \cdot 7$ & 0.855 & 0.962 \\
\hline LH (ng/ml) & & & $-2 \cdot 3$ & -10.5 & $6 \cdot 8$ & 0.612 & 0.921 \\
\hline Progesterone $(\mathrm{ng} / \mathrm{ml})$ & & & $-20 \cdot 1 \dagger$ & $-34.9 \dagger$ & $-1.9 \dagger$ & $0.032 \dagger$ & 0.288 \\
\hline SHBG $(\mathrm{nmol} / \mathrm{l})$ & & & 1.4 & -2.5 & $5 \cdot 6$ & 0.484 & 0.921 \\
\hline Testosterone (ng/dl) & & & 0.0 & $-3 \cdot 9$ & 4.0 & 0.994 & 0.994 \\
\hline Free testosterone $(\mathrm{ng} / \mathrm{dl})$ & & & -0.5 & $-4 \cdot 6$ & 3.8 & 0.818 & 0.962 \\
\hline Free androgen index & & & $-1 \cdot 6$ & -7.5 & 4.7 & 0.614 & 0.921 \\
\hline$P(\mathrm{mg})$ & $296 \cdot 3-698 \cdot 3$ & $700 \cdot 1-1843 \cdot 2$ & & & & & \\
\hline Oestradiol (pg/ml) & & & 0.5 & $-8 \cdot 2$ & $10 \cdot 1$ & 0.907 & 0.961 \\
\hline Free oestradiol $(\mathrm{pg} / \mathrm{ml})$ & & & 0.2 & $-8 \cdot 3$ & 9.5 & 0.961 & 0.961 \\
\hline $\mathrm{FSH}(\mathrm{mlU} / \mathrm{ml})$ & & & 5.5 & $-2 \cdot 1$ & 13.7 & 0.163 & 0.511 \\
\hline LH (ng/ml) & & & 2.5 & $-7 \cdot 0$ & 13.1 & 0.616 & 0.924 \\
\hline Progesterone $(\mathrm{ng} / \mathrm{ml})$ & & & -1.0 & -21.9 & $25 \cdot 4$ & 0.933 & 0.961 \\
\hline SHBG (nmol/l) & & & 2.9 & $-2 \cdot 4$ & 8.5 & 0.284 & 0.511 \\
\hline Testosterone $(\mathrm{ng} / \mathrm{dl})$ & & & $-2 \cdot 7$ & $-6 \cdot 9$ & 1.8 & 0.233 & 0.511 \\
\hline Free testosterone $(\mathrm{ng} / \mathrm{dl})$ & & & $-2 \cdot 8$ & $-7 \cdot 3$ & 1.9 & 0.233 & 0.511 \\
\hline Free androgen index & & & $-4 \cdot 1$ & -10.6 & $2 \cdot 8$ & 0.239 & 0.511 \\
\hline $\mathrm{Mg}(\mathrm{mg})$ & $65 \cdot 1-307 \cdot 9$ & $310 \cdot 5-539 \cdot 3$ & & & & & \\
\hline Oestradiol (pg/ml) & & & $-2 \cdot 7$ & $-12 \cdot 2$ & 7.9 & 0.605 & 0.908 \\
\hline Free oestradiol (pg/ml) & & & $-1 \cdot 3$ & -10.8 & $9 \cdot 3$ & 0.805 & 0.969 \\
\hline $\mathrm{FSH}(\mathrm{mlU} / \mathrm{ml})$ & & & $-5 \cdot 1$ & -13.0 & 3.4 & 0.229 & 0.515 \\
\hline $\mathrm{LH}(\mathrm{ng} / \mathrm{ml})$ & & & $5 \cdot 3$ & $-6 \cdot 0$ & 17.9 & 0.372 & 0.670 \\
\hline Progesterone $(\mathrm{ng} / \mathrm{ml})$ & & & 0.5 & -23.4 & $32 \cdot 0$ & 0.969 & 0.969 \\
\hline SHBG $(\mathrm{nmol} / \mathrm{l})$ & & & -4.5 & -9.9 & 1.2 & 0.117 & 0.515 \\
\hline Testosterone $(\mathrm{ng} / \mathrm{dl})$ & & & $-4.7 \dagger$ & $-9.2 \dagger$ & $0.0+$ & $0.049+$ & 0.441 \\
\hline Free testosterone $(\mathrm{ng} / \mathrm{dl})$ & & & -3.4 & $-8 \cdot 3$ & 1.7 & 0.192 & 0.515 \\
\hline Free androgen index & & & -0.6 & $-8 \cdot 1$ & 7.5 & 0.881 & 0.969 \\
\hline $\mathrm{Fe}(\mathrm{mg})$ & $3 \cdot 9-18 \cdot 0$ & $18 \cdot 1-52 \cdot 4$ & & & & & \\
\hline Oestradiol (pg/ml) & & & $-5 \cdot 0$ & $-13 \cdot 2$ & 4.0 & 0.265 & 0.646 \\
\hline Free oestradiol $(\mathrm{pg} / \mathrm{ml})$ & & & -3.9 & $-12 \cdot 0$ & 4.9 & 0.372 & 0.646 \\
\hline $\mathrm{FSH}(\mathrm{mlU} / \mathrm{ml})$ & & & $-2 \cdot 0$ & -9.1 & $5 \cdot 7$ & 0.601 & 0.646 \\
\hline $\mathrm{LH}(\mathrm{ng} / \mathrm{ml})$ & & & $-3 \cdot 7$ & $-12 \cdot 7$ & $6 \cdot 2$ & 0.445 & 0.646 \\
\hline Progesterone $(\mathrm{ng} / \mathrm{ml})$ & & & $-12 \cdot 9$ & -31.4 & $10 \cdot 6$ & 0.257 & 0.646 \\
\hline SHBG $(\mathrm{nmol} / \mathrm{l})$ & & & $-1 \cdot 2$ & $-5 \cdot 6$ & 3.4 & 0.595 & 0.646 \\
\hline Testosterone $(\mathrm{ng} / \mathrm{dl})$ & & & $-2 \cdot 1$ & $-6 \cdot 2$ & $2 \cdot 1$ & 0.324 & 0.646 \\
\hline Free testosterone $(\mathrm{ng} / \mathrm{dl})$ & & & -1.9 & $-6 \cdot 3$ & $2 \cdot 7$ & 0.419 & 0.646 \\
\hline Free androgen index & & & -1.6 & $-8 \cdot 2$ & $5 \cdot 4$ & 0.646 & 0.646 \\
\hline $\mathrm{Zn}(\mathrm{mg})$ & $2 \cdot 9-8 \cdot 0$ & $8 \cdot 0-113 \cdot 2$ & & & & & \\
\hline Oestradiol (pg/ml) & & & 3.6 & $-3 \cdot 1$ & $10 \cdot 8$ & 0.297 & 0.828 \\
\hline Free oestradiol (pg/ml) & & & 4.5 & $-2 \cdot 1$ & 11.5 & 0.184 & 0.828 \\
\hline $\mathrm{FSH}(\mathrm{mlU} / \mathrm{ml})$ & & & $2 \cdot 1$ & $-3 \cdot 4$ & 8.0 & 0.460 & 0.828 \\
\hline $\mathrm{LH}(\mathrm{ng} / \mathrm{ml})$ & & & $-2 \cdot 9$ & $-9 \cdot 7$ & 4.5 & 0.431 & 0.828 \\
\hline Progesterone $(\mathrm{ng} / \mathrm{ml})$ & & & -0.2 & $-16 \cdot 3$ & $19 \cdot 1$ & 0.987 & 0.987 \\
\hline SHBG $(\mathrm{nmol} / \mathrm{l})$ & & & $2 \cdot 2$ & $-1 \cdot 6$ & $6 \cdot 2$ & 0.264 & 0.828 \\
\hline Testosterone $(\mathrm{ng} / \mathrm{dl})$ & & & 0.7 & -2.5 & 4.0 & 0.659 & 0.867 \\
\hline Free testosterone $(\mathrm{ng} / \mathrm{dl})$ & & & 0.1 & $-3 \cdot 3$ & 3.6 & 0.972 & 0.987 \\
\hline Free androgen index & & & $-1 \cdot 1$ & $-6 \cdot 1$ & 4.2 & 0.674 & 0.867 \\
\hline $\mathrm{Cu}(\mathrm{mg})$ & $0.3-0.9$ & $0.9-12 \cdot 3$ & & & & & \\
\hline Oestradiol (pg/ml) & & & $-4 \cdot 1$ & $-10 \cdot 4$ & 2.5 & 0.217 & 0.663 \\
\hline Free oestradiol (pg/ml) & & & $-4 \cdot 0$ & $-10 \cdot 2$ & 2.5 & 0.221 & 0.663 \\
\hline $\mathrm{FSH}(\mathrm{mlU} / \mathrm{ml})$ & & & 4.7 & -1.0 & $10 \cdot 8$ & 0.109 & 0.663 \\
\hline $\mathrm{LH}(\mathrm{ng} / \mathrm{ml})$ & & & 3.4 & $-4 \cdot 0$ & 11.4 & 0.377 & 0.729 \\
\hline Progesterone $(\mathrm{ng} / \mathrm{ml})$ & & & -3.6 & -19.5 & $15 \cdot 3$ & 0.684 & 0.843 \\
\hline SHBG $(\mathrm{nmol} / \mathrm{l})$ & & & -0.6 & $-4 \cdot 4$ & $3 \cdot 3$ & 0.749 & 0.843 \\
\hline Testosterone (ng/dl) & & & $-1 \cdot 3$ & -4.5 & 1.9 & 0.405 & 0.729 \\
\hline Free testosterone $(\mathrm{ng} / \mathrm{dl})$ & & & -0.9 & $-4 \cdot 2$ & $2 \cdot 6$ & 0.614 & 0.843 \\
\hline Free androgen index & & & 0.2 & -4.9 & 5.5 & 0.950 & 0.950 \\
\hline $\mathrm{Mn}(\mathrm{mg})$ & $0.4-1 \cdot 8$ & $1 \cdot 8-10 \cdot 6$ & & & & & \\
\hline Oestradiol (pg/ml) & & & $4 \cdot 8$ & $-3 \cdot 3$ & 13.6 & 0.251 & 0.619 \\
\hline Free oestradiol $(\mathrm{pg} / \mathrm{ml})$ & & & 3.7 & $-4 \cdot 0$ & $12 \cdot 1$ & 0.355 & 0.619 \\
\hline $\mathrm{FSH}(\mathrm{mlU} / \mathrm{ml})$ & & & 1.8 & $-4 \cdot 8$ & 8.8 & 0.608 & 0.619 \\
\hline $\mathrm{LH}(\mathrm{ng} / \mathrm{ml})$ & & & $3 \cdot 1$ & $-5 \cdot 5$ & 12.5 & 0.488 & 0.619 \\
\hline Progesterone $(\mathrm{ng} / \mathrm{ml})$ & & & $-5 \cdot 1$ & $-22 \cdot 9$ & $16 \cdot 7$ & 0.619 & 0.619 \\
\hline
\end{tabular}


Table 3. Continued

\begin{tabular}{|c|c|c|c|c|c|c|c|}
\hline \multirow[b]{3}{*}{ SHBG $(\mathrm{nmol} / \mathrm{l})$} & \multirow{3}{*}{$<\mathrm{RDA}$} & \multirow{3}{*}{$\geq \mathrm{RDA}$} & \multicolumn{3}{|c|}{$<$ RDA $v . \geq$ RDA (ref) } & \multirow{3}{*}{$\begin{array}{l}\text { Raw }(P) \\
0.484\end{array}$} & \multirow{3}{*}{$\begin{array}{l}\begin{array}{l}\text { Adjusted for false } \\
\text { discovery rate }(P)\end{array} \\
0.619\end{array}$} \\
\hline & & & \multirow{2}{*}{$\frac{\% \text { Difference }}{1.4}$} & \multicolumn{2}{|c|}{$95 \% \mathrm{Cl}$} & & \\
\hline & & & & -2.5 & $5 \cdot 6$ & & \\
\hline Testosterone (ng/dl) & & & $-3 \cdot 0$ & $-6 \cdot 8$ & 1.0 & 0.139 & 0.619 \\
\hline Free testosterone $(\mathrm{ng} / \mathrm{dl})$ & & & -3.3 & $-7 \cdot 4$ & 0.9 & 0.118 & 0.619 \\
\hline Free androgen index & & & $-2 \cdot 8$ & $-8 \cdot 8$ & 3.6 & 0.380 & 0.619 \\
\hline Se $(\mu \mathrm{g})$ & $33.0-54.9$ & $55 \cdot 2-211.5$ & & & & & \\
\hline Oestradiol (pg/ml) & & & $-4 \cdot 2$ & -13.9 & $6 \cdot 7$ & 0.437 & 0.919 \\
\hline Free oestradiol (pg/ml) & & & $-2 \cdot 4$ & $-12 \cdot 1$ & $8 \cdot 3$ & 0.644 & 0.919 \\
\hline $\mathrm{FSH}(\mathrm{mlU} / \mathrm{ml})$ & & & $6 \cdot 1$ & $-2 \cdot 9$ & $16 \cdot 0$ & 0.191 & 0.825 \\
\hline LH (ng/ml) & & & $8 \cdot 7$ & $-3 \cdot 3$ & $22 \cdot 2$ & 0.163 & 0.825 \\
\hline Progesterone (ng/ml) & & & -14.5 & $-35 \cdot 6$ & $13 \cdot 3$ & 0.275 & 0.825 \\
\hline SHBG $(\mathrm{nmol} / \mathrm{l})$ & & & 0.3 & -5.9 & $6 \cdot 8$ & 0.931 & 0.972 \\
\hline Testosterone (ng/dl) & & & $-1 \cdot 3$ & $-6 \cdot 3$ & 4.0 & 0.620 & 0.919 \\
\hline Free testosterone $(\mathrm{ng} / \mathrm{dl})$ & & & -1.0 & $-6 \cdot 4$ & 4.7 & 0.715 & 0.919 \\
\hline Free androgen index & & & -0.2 & $-8 \cdot 2$ & 8.6 & 0.972 & 0.972 \\
\hline $\mathrm{Na}(\mathrm{mg})$ & $931 \cdot 2-1462 \cdot 1$ & $1561 \cdot 0-6553 \cdot 3$ & & & & & \\
\hline Oestradiol (pg/ml) & & & $-3 \cdot 2$ & $-16 \cdot 4$ & $12 \cdot 1$ & 0.667 & 0.750 \\
\hline Free oestradiol (pg/ml) & & & $-3 \cdot 1$ & $-16 \cdot 1$ & $11 \cdot 8$ & 0.663 & 0.750 \\
\hline $\mathrm{FSH}(\mathrm{mlU} / \mathrm{ml})$ & & & $21.3+$ & $7.5 \dagger$ & $36 \cdot 9 \dagger$ & $0.002 \dagger$ & $0.009 \dagger$ \\
\hline LH (ng/ml) & & & $36.8 \dagger$ & $16.5 \dagger$ & $60.5 \dagger$ & $0.0001 \dagger$ & $<0.0001 \dagger$ \\
\hline Progesterone (ng/ml) & & & $-36 \cdot 9 \dagger$ & $-56.5 \dagger$ & $-8.5 \dagger$ & $0.015 \dagger$ & $0.045 \dagger$ \\
\hline SHBG $(\mathrm{nmol} / \mathrm{l})$ & & & -2.4 & -10.5 & 6.5 & 0.585 & 0.750 \\
\hline Testosterone (ng/dl) & & & $-3 \cdot 3$ & -10.0 & 4.0 & 0.365 & 0.750 \\
\hline Free testosterone $(\mathrm{ng} / \mathrm{dl})$ & & & $-2 \cdot 8$ & -10.0 & $5 \cdot 1$ & 0.479 & 0.750 \\
\hline Free androgen index & & & -0.2 & $-11 \cdot 2$ & $12 \cdot 2$ & 0.976 & 0.976 \\
\hline $\mathrm{K}(\mathrm{mg})$ & $493 \cdot 8-2222 \cdot 3$ & $2230 \cdot 9-4242 \cdot 5$ & & & & & \\
\hline Oestradiol (pg/ml) & & & $-1 \cdot 2$ & $-8 \cdot 4$ & $6 \cdot 6$ & 0.759 & 0.854 \\
\hline Free oestradiol (pg/ml) & & & 0.5 & $-6 \cdot 7$ & 8.2 & 0.897 & 0.897 \\
\hline $\mathrm{FSH}(\mathrm{mlU} / \mathrm{ml})$ & & & $-4 \cdot 0$ & $-9 \cdot 8$ & $2 \cdot 2$ & 0.202 & 0.455 \\
\hline $\mathrm{LH}(\mathrm{ng} / \mathrm{ml})$ & & & $-2 \cdot 1$ & -9.8 & $6 \cdot 3$ & 0.616 & 0.792 \\
\hline Progesterone $(\mathrm{ng} / \mathrm{ml})$ & & & $8 \cdot 3$ & $-11 \cdot 2$ & 32.1 & 0.430 & 0.645 \\
\hline SHBG $(\mathrm{nmol} / \mathrm{l})$ & & & $-2 \cdot 5$ & $-6 \cdot 6$ & 1.7 & 0.262 & 0.472 \\
\hline Testosterone (ng/dl) & & & 2.5 & -1.0 & $6 \cdot 2$ & 0.167 & 0.455 \\
\hline Free testosterone $(\mathrm{ng} / \mathrm{dl})$ & & & 3.5 & -0.3 & 7.5 & 0.073 & 0.329 \\
\hline Free androgen index & & & 5.7 & -0.1 & 11.9 & 0.055 & 0.329 \\
\hline
\end{tabular}

$\mathrm{FSH}$, follicle-stimulating hormone; LH, luteinising hormone; SHBG, sex-hormone-binding globulin.

* Models were adjusted for age, BMI, race, physical activity, Mediterranean diet score, intakes of energy, fibre and protein, as well as other hormones. For progesterone, only measurements during the luteal phase were included. Intakes of K were categorised by the US average intakes (e.g. $2227 \mathrm{mg} / \mathrm{d}$ ).

† Statistically significant estimates and intervals.

Table 4. Dietary mineral intake by RDA and risk of sporadic anovulation* (Risk ratios (RR) and $95 \%$ confidence intervals)

\begin{tabular}{|c|c|c|c|}
\hline \multirow[b]{2}{*}{ Dietary minerals $(/ d)$} & \multirow[b]{2}{*}{$\geq \mathrm{RDA}$ (reference) } & \multicolumn{2}{|c|}{$<\mathrm{RDA}$} \\
\hline & & $\mathrm{RR}$ & $95 \% \mathrm{Cl}$ \\
\hline $\mathrm{Ca}(<1000 \mathrm{mg})$ & & 1.82 & $0.62,5.34$ \\
\hline $\mathrm{P}(<700 \mathrm{mg})$ & & 1.99 & $0.72,4.96$ \\
\hline $\mathrm{Mg}(<310 \mathrm{mg})$ & & 1.58 & $0.46,5.39$ \\
\hline $\mathrm{Fe}(<18 \mathrm{mg})$ & & 1.39 & $0.58,3.37$ \\
\hline $\mathrm{Zn}(<8 \mathrm{mg})$ & & 0.94 & $0.48,1.85$ \\
\hline $\mathrm{Cu}(<0.9 \mathrm{mg})$ & & $1 \cdot 12$ & $0.58,2.17$ \\
\hline $\mathrm{Mn}(<1.8 \mathrm{mg})$ & & $2.00 \dagger$ & $1.02,3.94 \dagger$ \\
\hline $\mathrm{Se}(<55 \mu \mathrm{g})$ & & 2.66 & $0.96,7.36$ \\
\hline $\mathrm{Na}(<1500 \mathrm{mg})$ & & $2.70 \dagger$ & $1.00,7.31 \dagger$ \\
\hline $\mathrm{K}(<2227 \mathrm{mg})$ & & 1.13 & $0.48,2.64$ \\
\hline
\end{tabular}

* All models were adjusted for age, BMI, race, physical activity, Mediterranean diet score and intakes of energy, fibre and protein. Intakes of dietary $\mathrm{K}$ were categorised by the US average intakes (e.g. $2227 \mathrm{mg} / \mathrm{d}$ ).

t Statistically significant estimates and intervals.

or undergo any diet regimes during the study period ${ }^{(21)}$, our data reflect the most common sources of minerals in a regular diet and the results are only generalisable to healthy regularly menstruating women not taking supplements. However, there are several strengths in our study as well. We used 24-h dietary recalls collected multiple times throughout the menstrual cycles to estimate usual intakes. This approach was used to reduce potential measurement error ${ }^{(50)}$, although more recalls may have been necessary to more adequately assess intake for specific minerals such as $\mathrm{Ca}$. Our data also capture a broad spectrum of the essential minerals via diet, and there is greater public health utility and easy interpretation of measures of daily mineral consumption.

Overall, our analyses suggest that intakes of specific dietary minerals, particularly $\mathrm{Na}$ and $\mathrm{Mn}$, may influence reproductive hormone concentrations and ovulatory function in premenopausal women with regular menstrual cycles. Minerals are mostly obtained via diet in the general population, and a range of whole food diets will likely provide adequate micronutrients to support normal ovulatory function. Given that essential minerals are abundant in easily accessible food items, our data suggest that dietary factors likely have important influences on ovulation and fertility. Moreover, the reproductive hormones investigated in our study affect not only women's reproductive health but general health across the life span. Thus, the associations with dietary minerals suggested in our study may be 
also of significance for other health outcomes related to reproductive organs or hormone levels.

\section{Acknowledgements}

The authors thank the BioCycle Study participants for their time and efforts.

This work was supported by the Intramural Research Program of the Eunice Kennedy Shriver National Institute of Child Health and Human Development, National Institutes of Health (Contract nos: HHSN275200403394C, HHSN275201100002I and Task 1HHSN27500001).

K. K. developed the analytic plan, performed statistical analyses and drafted and revised the manuscript. S. L. M. consulted on statistical analyses. J. W.-W., K. A. M., K. C. S., T. C. P., E. N. C. and S. L. M. reviewed and revised the manuscript for important intellectual content. J. W.-W. designed and conducted the BioCycle Study. All authors approved the final manuscript as submitted.

The authors declare that there are no conflicts of interest.

\section{Supplementary material}

For supplementary material/s referred to in this article, please visit https://doi.org/10.1017/S0007114518000818

\section{References}

1. Turnlund JR (1998) Human whole-body copper metabolism. Am J Clin Nutr 67, 960S-964S

2. Powell SR (2000) The antioxidant properties of zinc. J Nutr 130, $1447 \mathrm{~S}-1454 \mathrm{~S}$

3. Garfinkel L \& Garfinkel D (1985) Magnesium regulation of the glycolytic pathway and the enzymes involved. Magnesium $\mathbf{4}$, 60-72.

4. Culotta VC, Yang M \& Hall MD (2005) Manganese transport and trafficking: lessons learned from Saccharomyces cerevisiae. Eukaryot Cell 4, 1159-1165.

5. MacDonald RS (2000) The role of zinc in growth and cell proliferation. J Nutr 130, 1500S-1508S.

6. Ishikawa Y, Kudo H, Suzuki S, et al. (2008) Down regulation by a low-zinc diet in gene expression of rat prostatic thymidylate synthase and thymidine kinase. Nutr Metab 5, 12

7. Moe SM (2008) Disorders involving calcium, phosphorus, and magnesium. Prim Care 35, 215-237 v-vi.

8. Blaine J, Chonchol M \& Levi M (2015) Renal control of calcium, phosphate, and magnesium homeostasis. Clin J Am Soc Nephrol 10, 1257-1272

9. Murawski M, Bydlon G, Sawicka-Kapusta K, et al. (2006) The effect of long term exposure to copper on physiological condition and reproduction of sheep. Reprod Biol 6, Suppl. 1, 201-206.

10. Ruder EH, Hartman TJ \& Goldman MB (2009) Impact of oxidative stress on female fertility. Curr Opin Obstet Gynecol 21, 219-222.

11. Kim AM, Vogt S, O'Halloran TV, et al. (2010) Zinc availability regulates exit from meiosis in maturing mammalian oocytes. Nat Chem Biol 6, 674-681.

12. Bernhardt ML, Kong BY, Kim AM, et al. (2012) A zincdependent mechanism regulates meiotic progression in mammalian oocytes. Biol Reprod 86, 114.
13. Kurdoglu Z, Kurdoglu M, Demir H, et al. (2012) Serum trace elements and heavy metals in polycystic ovary syndrome. Hum Exp Toxicol 31, 452-456.

14. Chakraborty P, Ghosh S, Goswami SK, et al. (2013) Altered trace mineral milieu might play an aetiological role in the pathogenesis of polycystic ovary syndrome. Biol Trace Elem Res 152, 9-15.

15. Chavarro JE, Rich-Edwards JW, Rosner BA, et al. (2006) Iron intake and risk of ovulatory infertility. Obstet Gynecol 108, $1145-1152$

16. Muneyyirci-Delale O, Nacharaju VL, Altura BM, et al. (1998) Sex steroid hormones modulate serum ionized magnesium and calcium levels throughout the menstrual cycle in women. Fertil Steril 69, 958-962.

17. Pine M, Lee B, Dearth R, et al. (2005) Manganese acts centrally to stimulate luteinizing hormone secretion: a potential influence on female pubertal development. Toxicol Sci 85, 880-885.

18. Zagrodzki P \& Ratajczak R (2008) Selenium status, sex hormones, and thyroid function in young women. $J$ Trace Elem Med Biol 22, 296-304.

19. Sanchez-Capelo A, Cremades A, Tejada F, et al. (1993) Potassium regulates plasma testosterone and renal ornithine decarboxylase in mice. FEBS Lett 333, 32-34.

20. Basini G \& Tamanini C (2000) Selenium stimulates estradiol production in bovine granulosa cells: possible involvement of nitric oxide. Domest Anim Endocrinol 18, 1-17.

21. Wactawski-Wende J, Schisterman EF, Hovey KM, et al. (2009) BioCycle study: design of the longitudinal study of the oxidative stress and hormone variation during the menstrual cycle. Paediatr Perinat Epidemiol 23, 171-184.

22. Howards PP, Schisterman EF, Wactawski-Wende $\mathrm{J}$, et al. (2009) Timing clinic visits to phases of the menstrual cycle by using a fertility monitor: the BioCycle Study. Am J Epidemiol 169, 105-112.

23. US Department of Agriculture \& US Department of Health and Human Services (2010) Dietary Guidelines for Americans, 2010, 7 th ed. Washington, DC: US Government Printing Office.

24. US Department of Agriculture, Agricultural Research Service (2014) Nutrient Intakes from Food and Beverages: Mean Amounts Consumed per Individual, by Gender and Age, What We Eat in America, NHANES 2011-2012. Washington, DC: US Department of Agriculture.

25. Gorczyca AM, Sjaarda LA, Mitchell EM, et al. (2016) Changes in macronutrient, micronutrient, and food group intakes throughout the menstrual cycle in healthy, premenopausal women. Eur J Nutr 55, 1181-1188.

26. Barr SI, Janelle KC \& Prior JC (1995) Energy intakes are higher during the luteal phase of ovulatory menstrual cycles. Am J Clin Nutr 61, 39-43.

27. Wactawski-Wende J (2009) BioCycle study: design of the longitudinal study of the oxidative stress and hormone variation during the menstrual cycle. Paediatr Perinat Epidemiol 23, 171-184

28. Sjaarda LA, Schisterman EF, Schliep KC, et al. (2015) Dietary carbohydrate intake does not impact insulin resistance or androgens in healthy, eumenorrheic women. J Clin Endocrinol Metab 100, 2979-2986.

29. Lynch KE, Mumford SL, Schliep KC, et al. (2014) Assessment of anovulation in eumenorrheic women: comparison of ovulation detection algorithms. Fertil Steril 102, 511-518.

30. Robins J, Hernan M \& Brumback B (2000) Marginal structural models and causal inference in epidemiology. Epidemiology 11, 550 .

31. Cole SR \& Hernan MA (2008) Constructing inverse probability weights for marginal structural models. Am J Epidemiol 168, 656-664. 
32. Baudrand R, Campino C, Carvajal CA, et al. (2014) High sodium intake is associated with increased glucocorticoid production, insulin resistance and metabolic syndrome. Clin Endocrinol (Oxf) 80, 677-684.

33. Iranloye BO, Oludare GO, Morakinyo AO, et al. (2013) Reproductive parameters and oxidative stress status of male rats fed with low and high salt diet. J Hum Reprod Sci $\mathbf{6}$, 267-272.

34. McBurnie MI, Blair-West JR, Denton DA, et al. (1999) Sodium intake and reproduction in BALB/C mice. Physiol Behav 66, 873-879.

35. Fogarty AW, Lewis SA, McKeever TM, et al. (2009) Is higher sodium intake associated with elevated systemic inflammation? A population-based study. Am J Clin Nutr 89, 1901-1904.

36. Espey LL (1994) Current status of the hypothesis that mammalian ovulation is comparable to an inflammatory reaction. Biol Reprod 50, 233-238.

37. Whelton PK, Appel LJ, Sacco RL, et al. (2012) Sodium, blood pressure, and cardiovascular disease: further evidence supporting the American Heart Association sodium reduction recommendations. Circulation 126, 2880-2889.

38. Kim SI, Jang YS, Han SH, et al. (2012) Effect of manganese exposure on the reproductive organs in immature female rats. Dev Reprod 16, 295-300.

39. Massafra C, Buonocore G, Gioia D, et al. (1997) Effects of estradiol and medroxyprogesterone-acetate treatment on erythrocyte antioxidant enzyme activities and malondialdehyde plasma levels in amenorrhoic women. J Clin Endocrinol Metab 82, 173-175.

40. Ha EJ \& Smith AM (2003) Plasma selenium and plasma and erythrocyte glutathione peroxidase activity increase with estrogen during the menstrual cycle. J Am Coll Nutr 22, 43-51.

41. Zagrodzki P, Ratajczak R \& Wietecha-Posluszny R (2007) The interaction between selenium status, sex hormones, and thyroid metabolism in adolescent girls in the luteal phase of their menstrual cycle. Biol Trace Elem Res 120, 51-60.

42. Francisco SK \& Schuetz AW (1986) Calcium effects on progesterone accumulation and oocyte maturation in cultured follicles of Rana pipiens. J Exp Zool 240, 265-273.

43. Gallagher JC, Riggs BL \& DeLuca HF (1980) Effect of estrogen on calcium absorption and serum vitamin D metabolites in postmenopausal osteoporosis. J Clin Endocrinol Metab 51, 1359-1364.

44. Matkovic V, Goel PK, Badenhop-Stevens NE, et al. (2005) Calcium supplementation and bone mineral density in females from childhood to young adulthood: a randomized controlled trial. Am J Clin Nutr 81, 175-188.

45. Napoli N, Thompson J, Civitelli R, et al. (2007) Effects of dietary calcium compared with calcium supplements on estrogen metabolism and bone mineral density. Am J Clin Nutr 85, 1428-1433.

46. Harris HR, Chavarro JE, Malspeis S, et al. (2013) Dairy-food, calcium, magnesium, and vitamin D intake and endometriosis: a prospective cohort study. Am J Epidemiol 177, 420-430.

47. Kim K, Wactawski-Wende J, Michels KA, et al. (2017) Dairy food intake is associated with reproductive hormones and sporadic anovulation among healthy premenopausal women. J Nutr 147, 218-226.

48. Excoffon L, Guillaume YC, Woronoff-Lemsi MC, et al. (2009) Magnesium effect on testosterone-SHBG association studied by a novel molecular chromatography approach. I Pharm Biomed Anal 49, 175-180.

49. Kensicki E, Dunphy G \& Ely D (2002) Estradiol increases salt intake in female normotensive and hypertensive rats. $J$ Appl Physiol 93, 479-483.

50. Subar AF, Kipnis V, Troiano RP, et al. (2003) Using intake biomarkers to evaluate the extent of dietary misreporting in a large sample of adults: the OPEN study. Am J Epidemiol 158, $1-13$. 